\title{
An extremely rare giant skin cirsoid angioma with brain compression
}

Hongxu Chen, MD,* Zhigang Lan, MD,* and Jianguo Xu, MD

Neurology ${ }^{\circledR}$ 2018;90:481. doi:10.1212/WNL.0000000000005071

\author{
Correspondence \\ Dr. Xu \\ xujianguo_1229@163.com
}

Figure Photograph of the patient and preoperative contrast-enhanced CT
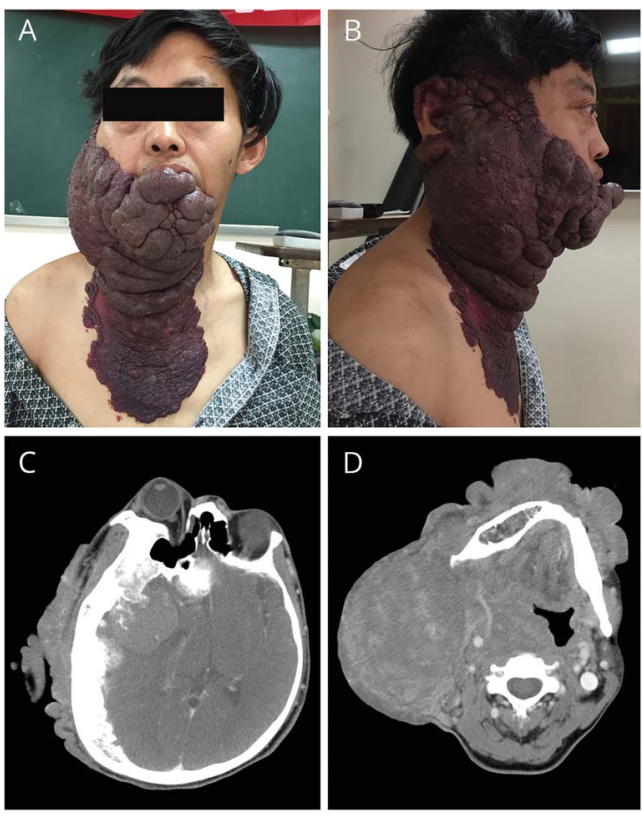

Physical examination found a congenital irregular reddish-brown cirsoid angioma in the territory of the head and neck and chest (A, B). Preoperative axial contrast-enhanced CT clearly showed heterogeneous enhancement of the lesion with extensive bone destruction. The mass encased the right common carotid artery and the internal and external carotid arteries, pushing the normal tissue to the left side. A soft tissue mass accompanied with the tumor compressed the right temporal lobe with a well-defined margin $(C, D)$.

A 49-year-old man presented with a congenital lesion involving head, neck, and chest regions (figure, A and B). There was an area of skin ulceration accompanied by secretions over the mass but no active bleeding. CT demonstrated a serpiginous subcutaneous and lytic lesion with a substantial compression of temporal lobe (figure, $\mathrm{C}$ and $\mathrm{D}$ ). The right external carotid artery was the main feeder to the lesion. The diagnosis was cirsoid angioma. A multidisciplinary approach combining endovascular, neurosurgical, and plastic surgery is intended for the patient. Cirsoid angioma is a congenital lesion that can grow over time and early intervention is preferred.

\section{Author contributions}

Hongxu Chen: study concept and design, acquisition of data. Zhigang Lan: analysis and interpretation of data. Jianguo Xu: study supervision, study concept and design, critical revision of manuscript for intellectual content.

\section{Study funding}

No targeted funding reported.

\section{Disclosure}

The authors report no disclosures relevant to the manuscript. Go to Neurology.org/ $\mathrm{N}$ for full disclosures.

*These authors contributed equally to this work.

From the Department of Neurosurgery, West China Hospital, Sichuan University, Chengdu, China. 


\section{Neurology}

\section{An extremely rare giant skin cirsoid angioma with brain compression \\ Hongxu Chen, Zhigang Lan and Jianguo Xu \\ Neurology 2018;90;481 \\ DOI 10.1212/WNL.0000000000005071}

This information is current as of March 5, 2018

$\begin{array}{ll}\begin{array}{l}\text { Updated Information \& } \\ \text { Services }\end{array} & \begin{array}{l}\text { including high resolution figures, can be found at: } \\ \text { http://n.neurology.org/content/90/10/481.full }\end{array} \\ \text { Subspecialty Collections } & \begin{array}{l}\text { This article, along with others on similar topics, appears in the } \\ \text { following collection(s): } \\ \text { All Imaging } \\ \text { http://n.neurology.org/cgi/collection/all_imaging } \\ \text { All Oncology } \\ \text { http://n.neurology.org/cgi/collection/all_oncology }\end{array} \\ & \begin{array}{l}\text { Information about reproducing this article in parts (figures,tables) or in } \\ \text { its entirety can be found online at: } \\ \text { http://www.neurology.org/about/about_the_journal\#permissions }\end{array} \\ \text { Permissions \& Licensing } & \text { Information about ordering reprints can be found online: } \\ \text { http://n.neurology.org/subscribers/advertise }\end{array}$

Neurology ${ }^{\circledR}$ is the official journal of the American Academy of Neurology. Published continuously since 1951, it is now a weekly with 48 issues per year. Copyright @ 2018 American Academy of Neurology. All rights reserved. Print ISSN: 0028-3878. Online ISSN: 1526-632X.

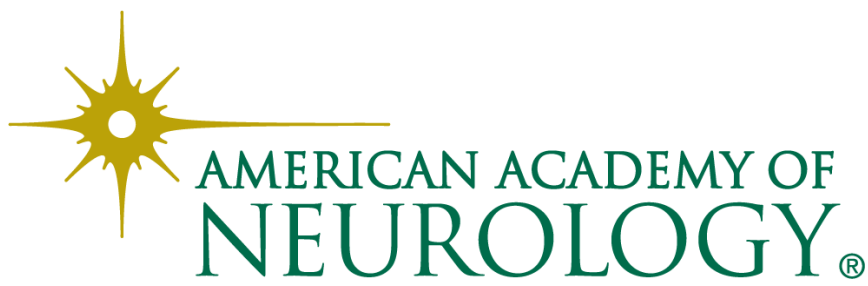

